\title{
POSSIBLE CAUSES INHIBITING THE PURCHASE OF CHINESE GROCERY OWN BRANDS: A PRELIMINARY STUDY
}

\author{
Wei Song \\ Business School, Black Hills State University, 1200 University St. Unit 9007, \\ Spearfish, SD 57783, USA \\ E-mail:wei.song@BHSU.edu
}

Received 01 April 2011; accepted 25 May 2011

\begin{abstract}
The aim of this preliminary study is to identify the possible causes inhibiting consumers from purchasing Chinese own brands. In view of the absence of literature on this aspect of commerce in Asia, a review of Western literature was conducted. The data for this study is from semi-structured in-depth interviews with Chinese retail consultants and grocery shoppers in Shanghai, China. The results of the study show that negative low price image, low perceived own brand quality, and the importance of "face" in Chinese culture are the key factors resulting in negative sentiment toward Chinese grocery own brands. The results of this investigation are expected to provide a basis for making recommendations for the use of both international and Chinese retailers when building Chinese grocery own brands. The findings of this study have been generated from a small group of interviewees in a single city and thus cannot be considered conclusive. Therefore further research in other cities of China and other Asian countries should be conducted. The study offers novel views from the consumer perspective on the unwillingness to buy own brands in emerging markets.
\end{abstract}

Keywords: Chinese consumers, grocery own brands, possible causes, consumer perspective, culture, preliminary study.

Reference to this paper should be made as follows: Song, W. 2012. Possible causes inhibiting the purchase of Chinese grocery own brands: a preliminary study, Journal of Business Economics and Management 13(2): 207-222.

JEL Classification: M16, M30, M31.

\section{Introduction}

Consumers' "own brand" buying behavior has been extensively researched in the Western literature, e.g., Halstead and Ward (1995); Dick et al. (1996); Steenkamp and Dekimpe (1997); Veloutsou et al. (2004); Kumar and Steenkamp (2007); Richardson (1997); Hansen and Singh (2008); Ailawadi et al. (2008); Ailawadi, Harlam (2004); Martos-Partal and Gonzalez-Benito (2009); Groznik and Heese (2010); Hyman et al. (2010) while the literature on own brands in Asia is limited. In particular, the causes that contribute to unsuccessful Chinese grocery own brands from the consumers' perspective are less discussed in the extant literature. Own Brands, as retailers' brands; have made significant penetration into supermarkets. Based on estimates by AC Nielsen (2009), own brands 
in Western markets continue to grow; many are now well established and enjoy some degree of recognition for quality and reliability. This is especially so in such markets as the USA, Canada and the UK (Nishikawa, Perrin 2005; Kumar, Steenkamp 2007).

AC Nielsen's own brand report (2009) shows that own brands have taken a significant share of Western markets with 46 percent of the market in Switzerland, 44 percent in the UK, 17 percent in US, and 14 percent in Australia. However, in emerging markets such as Asia their presence is noticeably low, with market shares in the order of 5 percent in Hong Kong, 3 percent in Singapore and only 1 percent in China (AC Nielsen 2009). Moreover, research has shown that consumers' acceptance level of own brands in emerging markets is lower than in the more developed markets, as evidenced in data from recent studies, e.g., research conducted by Veloutsou et al., from the Greek market in 2004; the comparative study undertaken by Anchor and Kourilova (2009) comparing UK and Czech Republic markets, based on consumer perception of the Tesco own brands. In addition, more recent work by Mandhachitara, Shannon, and Hadjicharalambous (2007) comparing US and Thai markets reveals that consumers in Thailand are less well disposed than their US counterparts toward own brands. It has been well documented that some lines of own brands have been introduced in the Asian grocery sector by the major retail chains but as yet they "have not been commercially successful"; a major reason for this is that consumers from Asia are prone to favor national and international brands (Mandhachitara et al. 2007). It is therefore an interesting conundrum to establish why, in spite of their remarkable success in the developed markets, own brands appear not to be succeeding in Asia, and particularly in China, which has a rapidly growing and diversifying consumer market.

Since the1990s the structure of the Chinese retail grocery sector has changed considerably, from a local store format to a modern international supermarket system. The major global retail chains have led and accelerated the transformation of the Chinese retail grocery sector. Based on AC Nielsen's Retail Census of 2008, there were more than 3.3 million retail stores, with an 18 percent increase in both store units and revenue turnover in comparison to 2007 (AC Nielsen 2009). AC Nielsen predicts that Chinese retail business will reach a market share of 60 percent of total fast moving consumer goods by 2015 (AC Nielsen 2009). Over the last fifteen years, Chinese own brands have emerged as a new phenomenon in the retail market. All major retail grocery chains in China have developed own brands in the hope of building store loyalty and increase their competitiveness. However, consumer confidence in own brands remains low, with only a 0.3 percent share of the personal care segment and a 1 percent share of all fast moving consumer goods products (FMCG), thus representing the lowest value share, per AC Nielsen report (2009), especially in the food sub-sector.

The definition of the term "own brand" can be simplified to mean products produced, packaged and sold with labeling that makes it proprietary to a retailer's ownership and its name on the package (Burt 2000; Berges-Sennou et al. 2004). There are various terms for own brands: own label, private label, house brand, retailer brand, and exclusive brand, store brand, etc., (DelVecchio 2001; Veloutsou et al. 2004; Lymperopoulos et al. 2010). These terms have been used by retailers and researchers interchangeably even though scholars such as McGoldrick believe these terms are different (2002). The 
most popular terms are "private label" and "own brand". The former is mainly used in Canada and the United States, while the latter is a common term in Europe, especially in the United Kingdom. This study will use own brands and private labels interchangeably.

The study reported in this paper was conducted in Shanghai, China, using semi-structured in-depth interviews as the primary research method. The main research question is: "Why do consumers not buy Chinese grocery own brands?" The investigation aims to explore the possible causes which inhibit consumers from purchasing own brands in the Chinese grocery sector. A review of Western literature was conducted, combined with Hofstede's framework of national culture constructs of Power Distance index (PDI) and Individualism (IDV). The objectives of the study are to search for the possible explanations for consumers' unwillingness to purchase own brands in the Asian market, using the case of China and then to provide recommendations on how international and domestic retailers can improve consumer own brand acceptance in the Asian market, with its huge opportunities in the retail sector. The study has taken two approaches to identify the factors behind consumers' skepticism towards buying own brands. The first approach is from a product perspective, examining the influence of product price and perceived quality on consumers' intention to buy own brands. The second approach is from a cultural perspective; this links Hofstede's PDI and IDV framework to Chinese consumers' preference to national brands and to the Chinese consciousness of and attitudes towards "face". In this context "face" means avoiding embarrassment due to low economic or social status; the purchase of own brands may be interpreted as an indication of low economic status. A discussion of the findings from in-depth interviews with Chinese retail consultants and supermarket shoppers is followed by a conclusion which includes a presentation of the implications for management and the limitations of the research, as well as the direction of further studies.

\section{Literature review}

Due to the limited number and scope of studies available in Chinese own brand buying behavior, the Western literature related to the factors that affect consumers' proneness to own brands was reviewed. The review focused on the factors associated with own brand purchasing behavior and the cultural influences on consumers' own brand buying decision. Two sets of the literature were consulted: a) Factors related to own brand buying behavior and b) The influence of national culture. The research has found that brand influences are closely associated with both product and cultural backgrounds of the consumers (Guerrero et al. 2000) and thus with the divergence of own brand buying behavior that exists between East and West. These theories serve as the framework for this study and the foundation to the research question under investigation.

\subsection{From product perspective}

Although many factors have been identified which are related to the making of own brand purchasing decisions for consumers, two stand out as crucial to consumers' intention to purchase. These factors are low price and high perceived quality (Burton et al. 1998; Sinha, Batra 1999; Zielke, Dobbelstein 2007; Baltas, Argouslidis 2007; Anchor, Kourilova 2009). The research has further confirmed that the propensity to purchase 
own brands is greatly influenced by the relationship between price and quality (Gomez, Fernandez 2009; Lymperopoulos et al. 2010), and the main driver of own brand acceptance is its relatively low price and the improved quality (Cooper, Nelson 2003; Lymperopoulos et al. 2010).

\subsubsection{Low price}

Although the doubts about the quality of own brands have diminished, low price is still one of the main factors that influences consumers to buy own brands (Morris 1979; Burton et al. 1998; Sinha, Batra 1999; Burt 2000; Chandon et al. 2000). In Myers' (1967) early work it was believed that low price was the main factor for customers to accept a private label. Over the years, the notion that own brands always come at a lower price has been well received (Burton et al. 1998; Burt 2000). Low price has repeatedly been reported to be the most important determinant of customers' purchases of own brand products (Myers 1967; Morris 1979; Sinha, Batra 1999). On average, own brands are priced $25 \%-30 \%$ below national brands (e.g., Kumar, Steenkamp 2006). These studies support the conclusion that lower price is a very critical determinant in the process of making a purchasing decision. The research reported in the mainstream literature has generally concluded that lower price is the one of the most important factors causing UK consumers to purchase own brands (Baltas 1997, 2003; Burt 2000; Veloutsou et al. 2004). Data from both Key Note (2003) and Business Insights (2003) has demonstrated that price is a major factor in how consumers decide what to buy. This point has been reaffirmed in recent studies (e.g., Anchor, Kourilova 2009).

Traditionally, one of the attractive attributes of own brands has always been their low price, which is appealing to the lower income demographic. Therefore, one would expect emerging markets such as China to occupy a larger own brand market share than Western markets because average income levels are much lower than in the Western market. Yet in China, own brands are not well received; Chinese consumers view low price as an index that reflects low quality in the own brand products. A model developed by Rao and Monroe (1989) suggests that consumers could perceive price in both ways. Their research reports a strong perception that higher price denotes better quality while lower price indicates an inferior product. There is also the issue of status in Chinese society. Buying lower price products results in reduction in perceived status, a factor which directly influences consumers' preference (Rao, Monroe 1989). This finding explains, in large measure, why consumers in China have not shown a strong appreciation of the value of the low price of own brands. In spite of the lower price, higher perceived quality is still the primary reason that attracts consumers to the own brand products and quality tends to be the critical winning factor over low price (Burt 2000; Veloutsou et al. 2004; Martos-Partal, Gonzalez-Benito 2009; AC Nielsen 2009).

\subsubsection{Perceived quality}

The new generation of own brands blurs the traditional trade-off between price and quality. Some of the newcomers are themselves of very high quality brands that compare well with traditional manufacturers' brands (Kilian et al. 2008). The shift in own brand perception from a focus on low price to high quality is what has driven the continued growth of own brands in Western markets (Kilian et al. 2008). Based on AC 
Nielsen's own brand report (2009), own brand quality which is at least equivalent to the well known national brands is recognized by more than 70 percent of the consumers in the US and Europe. Many Western retailers, such as Tesco and Mercadona, introduce high quality new products on a yearly basis, in competition with national brand manufacturers (Huang, Huddleston 2009). A classic example to support this viewpoint in the UK market is that of Sainsbury's Cola, which competes on store shelves against Coca-Cola, one of the strongest manufacturers' brands in the world. The success of Sainsbury's Cola proves that the power of own brands in the UK grocery sector is strong enough to succeed against a national brand, even a world leading brand such as Coke. Since the mid 1990s many retailers have repositioned their own brands to bring them up to a standard where they can challenge manufacturers' brands (Choi, Coughlan 2006). For example, UK retailers started to enhance their premium own brand ranges. This has most negatively and directly impacted the market share of manufacturers' brands (Nandan, Dickinson 1994; Jonas, Roosen 2005).

Own brands from UK retailers, such as Tesco's "Finest", Sainsbury's "Taste the Difference", and ASDA's "Extra Special" not only provide excellent quality, which can be a "key differentiating agent" between retailers (Business Insights 2003) but also create a special symbolic value for the customers (Unsitalo 2001) reflecting the personality of the retailer (Burt, Davis 1999; Huang, Huddleston 2009). In the UK market, own brands have been regarded as being equally as good as the leading brands (Fernie, Pierrel 1996; Burt 2000; Cooper, Nelson 2003). A recent study has shown that more than 70 percent of Tesco customers purchase "Finest" own brands on a regular basis (Lyons 2008). Own brand research has confirmed that higher perceived quality of own brands becomes the key factor in influencing consumers to purchase own brands (Batra, Sinha 2000; Burt 2000; Kara et al. 2009; AC Nielsen 2009; Anchor, Kourilova 2009; Walsh, Mitchell 2010). While extant studies show that grocery consumers in Western markets are becoming less loyal to national brands, purchasers from the grocery sector in Asia have consistently demonstrated a strong preference for national and international brands in comparison to own brands (De Mooij, Hofstede 2002; Brady et al. 2003; Anchor, Kourilova 2009). In China, only 17 percent of shoppers believe that own brands have the same quality as national and international brands, while the majority of own brand shoppers purchase own brands due to their lower price rather than from any considerations about quality (AC Nielsen 2009). There is a need to better "educate" consumers in China to enable them to have a better informed perception of own brand quality (AC Nielsen 2009). Before own brands can be expected to enjoy a reasonable market share in these markets, it is essential to improve the perception of own brand quality (Richardson et al. 1996; Batra, Sinha 2000).

\subsection{From a cultural perspective}

In addition to the factors of price and quality, cultural influences could alter consumers' own brand shopping behavior significantly. With respect to this study, two groups of theories of cultural influence have been considered: Hofstede's Power Distance Index (PDI) \& Individualism (IDV) model and Chinese "face" consciousness-Chinese "Lianmian" concept. 


\subsubsection{Hofstede's power distance and individualist constructs}

In recent years, research on the influence (or impact) of cultural factors on global marketing has attracted much interest. Many studies have demonstrated the importance of the cultural factors/considerations in adapting branding strategy to take cultural biases in consumer behavior into account. Among several models, the Hofstede model has received a great deal of attention (Hofstede 2001; Hofstede, G., Hofstede, G. J. 2005; De Mooij, Hofstede 2010), and Hofstede's five dimensional model of national culture has directly influenced international marketing research. The model evaluates the different types of cultures based on the seventy six countries investigated, on a scale of 0 to 100. Lower scores indicate a weaker level of influence of a given dimension, and vice versa. Table 1 shows the raw scores from selected countries. Based on current studies (Mandhachitara et al. 2007; Martos-Partal, Gonzalez-Benito 2009; AC Nielsen 2009), countries from the East present the lower level of own brand penetration while countries from the West have strong own brand market shares.

Table 1. Raw scores for the selected countries based on Hofstede's model

\begin{tabular}{lccccc}
\hline \multicolumn{1}{c}{ COUNTRIES } & PDI & UAI & MAS & IDV & LTO \\
\hline China & 80 & 30 & 66 & 20 & 118 \\
\hline Malaysia & 104 & 36 & 50 & 26 & $\mathrm{a} / \mathrm{a}$ \\
\hline Thailand & 64 & 64 & 34 & 20 & 56 \\
\hline United Kingdom & 35 & 35 & 66 & 89 & 25 \\
\hline United States & 40 & 46 & 62 & 91 & 29 \\
\hline Spain & 57 & 86 & 42 & 51 & $\mathrm{n} / \mathrm{a}$ \\
\hline
\end{tabular}

Source: Adapted from Internet: http://www.geert-hofstede.com/hofstede_dimensions.php?culture1= 18\&culture2=94 (retrieved on 7 March 2011)

Table 1 shows that Asian countries have much higher scores on Power Distance Index (PDI) - a crude measure of the extent to which society have disparities in the distribution of power - and lower scores on Individualism (IDV) than is the case for Western countries. This also partially explains why consumers from Asian countries tend to appreciate national and global brands more than own brands. In PDI cultures, a person's social status is extremely important and effort is invested in presenting appearances, actions, belongings and all other ways to manifest to other members of the society the appearance of having high status so that appropriate respect could be received. $\mathrm{Na}$ tional and global brands can serve that very purpose well as they are seen and used as symbols of prosperity and therefore status. Thus, for example, some luxury articles and well known alcoholic beverages are often used as status symbols that satisfy the status need (De Mooij, Hofstede 2010). The study reported by Batra and Sinha's (2000) states that Eastern Asian consumers prefer to pay higher prices on well-known brands and are much less interested in own brands.

The study suggests that, in a collectivist culture, consumers prefer national and global brands to own brands as compared to consumers from the more individualist cultures 
such as the UK and USA; the consumers in the latter countries would more readily accept own brands for their brand choice (De Mooij, Hofstede 2002). Other studies have also confirmed that developed countries have become less brand- loyal and thus own brands are prevalent in these markets (Anchor, Kourilova 2009). The collectivist culture enhances the notion of "face", status and power distance, while national and international brands could bring status to consumers while reducing the risk of losing "face" (Schutte, Ciarlante 1998; Mandhachitara et al. 2007).

\subsubsection{Chinese "Face" consciousness}

Collectivist culture stresses the importance of status and "face" which links to the concept of risk aversion (Samli 1995; Moss, Vinten 2001; De Mooij, Hofstede 2010). Although Asian culture has been ranked higher on Uncertainty Avoidance Index (IDI), Chinese culture has lower UAI with a score of 30. However, a lower UAI does not necessarily imply a lower degree of risk aversion. UAI can be confused with risk aversion but in reality they are different, even though a connection between these two exists (Roth 1995). Risk aversion emphasizes the reduction of risk. In the Chinese case, reducing or eliminating risk assures saving "face" which is consistent with the principle of collectivist culture.

Chinese "face" consciousness is the key social norm in China, and is represented by the Chinese term/concept of "Lianmian". One of the influential studies in this field is Qu's Chinese Lianmian Concept. The study stresses that this phenomenon has a great impact on all aspects of Chinese life and analyzes the rationale behind certain aspects of Chinese behavior. Qu's seminal work: "Chinese Lianmian Guan" has defined that this phenomenon is China-specific, partly because Chinese culture stresses collectivism rather than individualism. Therefore, in Chinese culture the opinions of other people are more important than that of self-evaluation in a social setting. Buying national or global brands ensures their status has been clearly demonstrated to others; therefore the "face" is saved and "risk" is avoided (Mandhachitara et al. 2007). Some research has also suggested collectivist cultures are more open to national or international brands rather than own brands (De Mooij, Hofstede 2002). This finding helps to explain the case of China where most Chinese consumers have shown great interest in named brands as opposed to own brands.

\section{Methodology}

This study was undertaken using a qualitative approach (Blaikie 2000). The goal of qualitative study is to explore complex social phenomena to gain deeper and more meaningful understanding without necessarily relying on finite measurements (Malterud 2001). The data collection process of this study followed the procedures of phenomenological inquiry (Creswell 1998). Qualitative study usually involves data collection, content origination and information interpretation (Malterud 2001). The main data source was drawn from the semi-structured in-depth interviews with grocery retail consultants and supermarket shoppers in Shanghai, China. Theoretical and purposeful sampling was employed to establish the sampling frame (Strauss, Corbin 1998). A total of 17 
"subjects" were interviewed; including four consultants and thirteen regular supermarket shoppers. The list of the consultants was provided by the Shanghai Chain Store Association, who also recommended six retailer chains with a relatively long history of own brand operations.

These Consultants are experts in the grocery sector who have a solid background in Chinese store-brand development. Thirteen grocery shoppers from six major supermarkets in Shanghai were interviewed. Each of the consultants was asked about their experiences of own brand development and the factors they considered responsible for shopper's unwillingness of purchasing Chinese own brands. The theories and concepts of cultural impact on consumer buying behavior were explained at the beginning of the interview to ensure a clear understanding of the topic addressed. See Table 2 for the consultants interviewed.

Table 2. Consultants interviewed in Shanghai

\begin{tabular}{cllc}
\hline Number & \multicolumn{1}{c}{ Interviewees } & \multicolumn{1}{c}{ The specialty of the Interviewees } & Ownership \\
\hline $\mathrm{C} 1{ }^{*}$ & CEO & Supermarket and retail private labels & GO \\
\hline C2 & Vice President & Private label development & PO \\
\hline C3 & President & $\begin{array}{l}\text { Category Management and Supply } \\
\text { Chain Management }\end{array}$ & PO \\
\hline C4 & The Secretary & Chain Store Marketing Research & GO \\
\hline
\end{tabular}

Note: Ownership: Government owned (GO) and private owned (PO). Consultants are people who have direct involvement with and a solid working knowledge of private label development. Their opinions are more disciplined and usually presented in an analytical fashion. The approach of the consultants is different from that of the retailers, who possess a more task-oriented approach. ${ }^{*} \mathrm{C} 1$ stands for consultant 1 and $\mathrm{C} 2$ stands for consultant 2, etc.

To ensure the validity and reliability of the investigation, the shoppers to be interviewed had to meet the following two requirements: they must be a regular grocery shopper and must have a good knowledge of Chinese grocery own brands. Selection of the interviewees from amongst regular grocery shoppers was done in two routes: from the authors' own network and from a random selection in supermarkets. Among these interviewees, four were friends of the author. Five were author's friends' referrals; these were either author's friends' friends or their acquaintances. The remaining four interviewees were randomly selected, based on the shopper's convenience and the author's judgment, while they were shopping in the stores. The interviews with the grocery shoppers were taken in the stores, café shops, teahouses, and the food courts in the mall. Repeated follow-up calls were placed to two important informants (i.e., the grocery shoppers) who have good knowledge of Chinese own brands, both through their personal interest in own brands and extensive shopping experience in supermarkets. The conversations with these two interviewees provided rich insight into consumers' attitudes and feelings toward Chinese own brands.

Detailed onsite and offsite interview notes were taken which enabled the author to use the textual data to record the direct quotes, develop the categories and interpret the 
contents. Three categories were built based on the themes drawn from literature and emerging from the investigation:

a) Negative price image.

b) Low perceived quality and

c) Cultural impact (i.e., Chinese "face" consciousness).

These categories will be addressed in the section of findings and discussions.

The language of the interview was Chinese mandarin and Shanghainese - a Chinese dialect. All the direct quotes used in this study were translated from mandarin and Shanghainese. Member checking was performed at the end of each interview and backtranslation was also conducted using translation software and consulting with an English professor in China.

\section{Findings and discussion}

A variety of factors may discourage consumers from buying grocery own brands. In this study the focus and parameters found to be key by other researchers were used as benchmarks, namely, low price image, low perceived quality, and national cultural influences in relation to own brand buying behavior in China. These factors may provide an explanation for why Chinese consumers are less interested in buying own brands. The study has identified three most common causes: negative low price image, low perceived quality, and Chinese "face" consciousness.

\subsection{Low price image}

Prior research indicated that low price could be one of the positive attributes to encourage consumers to buy own brands, but it also could be a negative factor, if it is construed to be an indicator of inferior quality of the own brands (Monroe, Krishnan 1985). In China, own brands have adopted an "Everyday Low Price" (EDLP) strategy even though extensive store promotion with the "on sale" approach is normal practice $(\mathrm{C} 1)$. Chinese consumers generally tend to infer that low price is equivalent to low quality, as the following statements from a Chinese supermarket shopper supported this notion:

Although I have not bought own brands, I would never consider them because the low priced products are always questionable in China as there must be some reasons behind the low priced product (shopper A).

Large price gap between own brands and manufacturers' brands brings doubt about food safety and health in ingredients, as described by shopper B.

Some own brand products are priced very low; for example, own brand bread is $\$ 0.76$ while national branded one is $\$ 1.50$. I could not imagine how could the own branded bread be safe and have healthy ingredients if it is only half the price of the branded bread.

Buying low priced own brands is also considered to signify low financial status which would make the consumers feel uncomfortable when buying them because people would consider them to be financially challenged: 
Buying own brand products makes me feel depressed as majority of own brand consumers are either unemployed or under welfare. I do not want people to think I am associated with this group (Shopper D).

\subsection{Perceived quality}

Responses from the Chinese grocery shoppers have shown a lower level of perceived quality on own brands across all categories; this implies a low acceptance rate for own brands in China. Respondents who had not bought own brands in China's supermarket automatically assumed that the quality of these products was unacceptable. There are several reasons for this negative perception other than the low price itself.

\subsubsection{The unknown suppliers}

In comparison to Western markets, own brands in China are mostly made by unknown suppliers. They are either small companies or have newly produced own brands. Therefore, the product specifications and quality control for these firms are the weaker areas $(\mathrm{C} 2, \mathrm{C} 3)$. By regulation, own brand suppliers must print their information on the product label so customers can tell who is the supplier for this particular own brand just by reading the label (C4). As most of these suppliers are new and unfamiliar to customers, the level of trust in the own brands they produce is low.

I have never heard of these own brand suppliers before. My instinct told me these unknown suppliers usually would not take the responsibility well if something goes wrong. I do not want to take the risk, especially for the food products (Shopper F).

\subsubsection{Higher suppliers' turnover rate}

In China the turnover rate for own brand suppliers is very high (C3). Retailers frequently change own brand suppliers whenever they believe it necessary. Conversely, suppliers can also leave the retailers for various reasons. The high turnover rate of own brand suppliers is due to some of the following reasons. First, when considering bids by suppliers to provide goods, many retailers evaluating own brand contracts make their decisions almost exclusively on price, and often take the lowest bid (C1). Since most own brands in China are not technologically advanced, the replacements for suppliers can be found easily. Second, the profit margin on own brands is very slim, discouraging own brand suppliers from establishing long term relationships with the retailer $(\mathrm{C} 4)$. If they are not getting value from the relationship, these suppliers would change retailer chains or begin to create their own manufacturers' brands. Due to the instability of own brand suppliers, customers may have concerns about whether they can find the supplier when the product has problems, because retailers are not responsible for own brand quality issues.

All the questions regarding the own branded products would be directed to suppliers. If the suppliers leave the retailer chain, then the customers would fall between the cracks i.e., retailers and suppliers (Shoppers G).

In the West, retailers usually assume responsibility for problems related to the merchandise sold from their chains. In China, many of these unknown suppliers lack the capaci- 
ties and skills to make the products. This is also one of the reasons that the turnover rate of own brand suppliers in the supermarkets is significantly high. It is very common for own branded products to be discontinued at short notice or after a short period on the market $(\mathrm{C} 3)$.

\subsubsection{Non-Shanghai suppliers}

Shanghai is the commercial center of China. The city itself is a brand that signifies quality and reputation. Consumers would feel more comfortable purchasing products made by Shanghai suppliers rather than from other regions. This preference is particularly stressed by consumers in Shanghai. However, many own brands in the supermarkets are produced by suppliers who reside in other towns, or provinces and not Shanghai. This is such an important element that some of the own brand suppliers even use a Shanghai mailing address or rent offices in Shanghai while their facilities are in other places (C2). The location of the suppliers is one of the major issues for Chinese consumers. The factories from which these products come are usually not located in the major cities, such as Shanghai, Beijing, Tianjin or Guangzhou and just for that reason alone, the producers' reputation can be greatly diminished.

\subsection{4. "Non-control" relationship with the suppliers}

There are two main types of own brands based on their production methods in China: "tiepai" and "dingpai" own brands. The former mainly refers to re-packaging of products provided by a manufacturer/supplier while the latter refers to the own brands that are bespoke orders from suppliers who follow the retailers' requirements. The "tiepai" method is to select existing products from the suppliers who can offer the lowest price for the product requested. They are a particular supplier's standard product distributed without modification except for the packaging. Many first priced (i.e., generic) products, especially sold in the discounters, i.e., lowest price and lower quality own label products in the market, are made by this production method. The "dingpai" method means that the retailers select a production line from a supplier based on preset requirements. The retailers' involvement with the product is minimal and the retailers do not have any control in the quality (C3). Therefore consumers view own brands not as so much as retailers' brands rather as unknown label products with some retailers' name.

I am shopping at the same chain stores but I have never related this retailer to its own brands. I believe these own brands are unknown labels which have nothing to do with the retailer but its name. I trust this chain as it provides a wider range of national and international brands but I question its ability to make its own brands with the unknown suppliers (Shopper H).

\subsubsection{Opaque plastic packaging}

Own brand packaging is not a major factor which inhibits Chinese consumers from purchasing own brands. Chinese own brands tend to use opaque packaging that is fully covered and obscures the product rather than transparent ("see thru") packaging. Chinese consumers want to see what the product looks like before buying it, while most own branded food products are fully covered and do not expose or reveal enough of the 
product for consumers to see. In the case of food products, consumers then cannot see the food unless they open up the package. In China it is customary to touch, smell and see or taste food products before purchasing (C3, Shopper 5). When food products are wrapped with opaque plastic packaging consumers become suspicious of the quality, because in their view the quality of many foods can be assessed by seeing them.

\section{3. "Face" consciousness}

Chinese consumers have negative feelings on low price as it relates to product quality. They assume a direct relationship between price and quality, and so to them low price indicates low quality. The explanation for this is partly due to cultural influences, specifically, Chinese "face" consciousness. Chinese people believe that "expensive" equals "high status", and so appearing to be able to afford high prices increases one's esteem in the face of others. This behavior in its turn reduces social distance in relation to the upper classes and so strengthens the relationship (guanxi) with the higher society. Based on Hofstede's model, Chinese score high on PDI and rank low on IDV. In power distance culture people feel a need to gain social status, which explains why consumers from countries with high PDI scores tend to be more interested in buying luxury brands (De Mooij, Hofstede 2010). Buying own brands for the Chinese is associated with loss of status or "losing face". Yet, "face" for the Chinese is associated with people's economic status (Suedo 2004). In the Hofstede model, the cultures with high PDI ranking generally present lower scores on IDV. Chinese consumers are always extremely concerned about other people's views on their status when choosing a brand. Based on the interview responses, consumers' concerns about the low price image which could be an indication of inferior quality while the poor quality products have a higher "risk" in the sense of a higher chance of "losing face" and being held in lower esteem by other people. Historically Chinese consumers have had strong brand consciousness and believe that purchasing brands associated with high price tags was a means to gaining higher social status, and thus showing a better "face".

\section{Conclusion}

The findings of this study have several implications for domestic and international retailers when building own brands in China's market. First, there is a need to educate Chinese consumers that low price is one of the positive attributes of own brands in developed markets, and that it will be the same in the emerging market. It must be shown that the lower price of own brands is not due to the low quality, but rather to low distribution channel cost. Second, retailers should not only build strong relationships with suppliers who can commit to own brand production development; they should also be the leaders and designers of the own brands by using their retailer chains' reputation and store image. It is extremely important that perceptions of own brand quality be improved. Third, Chinese brand consciousness, when influenced by Chinese culture, provides the opportunity to develop premium own brands. Retailers should take this opportunity to enhance the concept that premium own brands are just as good as manufacturers' brands but have a lower price. Or it can match or exceed the quality 
of manufactures' brands but charge the same price as national brands. There are many successful examples in developing premium lines in Western markets. For example, the premium lines from Tesco, Ukrops, and Loblows are exemplars of quality own brands.

There are some limitations to this study. Because the sample was chosen from a single city, Shanghai, it would be reasonable to question whether the interview data is biased or inadequate as a sample. It is therefore acknowledged that this is only a preliminary study and that, to make it a more meaningful baseline study, more extended sampling needs to be conducted in different cities, using a larger and more diverse sample pool. In addition to consultants and consumers, retailers and suppliers should be included as part of the broadening of the sample population. This would make it possible for a more comprehensive survey to be done, using quantitative methods and for a larger scale of the analysis. Although referrals from the friends can be used as consumer subjects, randomly selected consumers/shoppers should be the majority of the interviewees in the future studies. This may reduce the possibility of biased responses.

\section{Acknowledgement}

This research has been partially funded by School of Business and Economics, Thompson Rivers University, BC. Canada.

\section{References}

AC Nielsen 2009. Who will win the battle of the shelf? Branded or private label products [online], [cited 08 October 2010]. Available from Internet:

http://cn.en.acnielsen.com/site/index.shtml

Ailawadi, K.; Harlam, B. 2004. An empirical analysis of the determinants of retail margins: the role of store brand share, Journal of Marketing 68(1): 147-166.

http://dx.doi.org/10.1509/jmkg.68.1.147.24027

Ailawadi, K.; Pauwels, K.; Steenkamp, J. B. E. M. 2008. Private-label use and store loyalty, Journal of Marketing 72(November): 19-30. http://dx.doi.org/10.1509/jmkg.72.6.19

Anchor, J.; Kourilova, T. 2009. Consumer perceptions of own brands: international differences, Journal of Consumer Marketing 26(6): 437-449.

Baltas, G. 1997. Determinants of store brand choice: a behavioral analysis, Journal of Product and Brand Management 6(5): 315-324. http://dx.doi.org/10.1108/10610429710179480

Baltas, G. 2003. A combined segmentation and demand model for store brands, European Journal of Marketing 37(10): 1499-1513. http://dx.doi.org/10.1108/03090560310487211

Baltas, G.; Argouslidis, P. C. 2007. Consumer characteristics and demand for store brand, International Journal of Retail and Distribution Management 3(5): 328-341.

http://dx.doi.org/10.1108/09590550710743708

Batra, R.; Sinha, I. 2000. Consumer-level factors moderating: the success of private label brands, Journal of Retailing 76(2): 175-191. http://dx.doi.org/10.1016/S0022-4359(00)00027-0

Berges-Sennou, F.; Bontems, P.; Requillart, V. 2004. Economies of private labels: a survey of literature, Journal of Agriculture and Food Industrial Organization 2(3): 1-23.

Blaikie, N. 2000. Designing Social Research: the Logic of Anticipation. Cambridge: Polity Press. Brady, L.; Brown, A.; Hulit, B. 2003. Private Label: Threat to Manufacturers, Opportunity for Retailers. Chicago: Boston Consulting Group. 
Burt, S.; Davis, S. 1999. Follow my leader? Look-alike retailer brands in non-manufacturerdominated product markets in the UK, International Review of Retail, Distribution and Consumer Research 9(2): 163-185.

http://dx.doi.org/10.1080/095939699342624

Burt, S. 2000. The strategic role of retail brands in British grocery retailing, European Journal of Marketing 34(8): 875-890. http://dx.doi.org/10.1108/03090560010331351

Burton, S.; Lichtenstein, D. R.; Netemeyer, R. G.; Garretson, J. A. 1998. A scale for measuring attitude towards private label products and an examination of its psychological and behavioral correlates, Journal of the Academy of Marketing Science 26(4): 293-306.

http://dx.doi.org/10.1177/0092070398264003

Business Insights. 2003. Consumer Goods Report: the Future of Private Label Food and Drink: Growth Strategies for Retailers and Manufacturers.

Chandon, P.; Wansink, B.; Laurent, G. 2000. A congruence framework of sales promotion effectiveness, Journal of Marketing 64(4): 65-81. http://dx.doi.org/10.1509/jmkg.64.4.65.18071

Choi, C.; Coughlan, A. T. 2006. Private label positioning: quality versus feature differentiation from the national brand, Journal of Retailing 82(2): 79-93.

http://dx.doi.org/10.1016/j.jretai.2006.02.005

Cooper, S.; Nelson, M. 2003. Economy line foods from our supermarkets and brand name equivalents: a comparison of their nutrient contents and cost, Journal of Human Nutrition and Dietetics 16: 339-347. http://dx.doi.org/10.1046/j.1365-277X.2003.00465.x

Creswell, J. W. 1998. Qualitative Inquiry and Research Design: Choosing Among Five Traditions. Thousand Oaks, CA: Sage.

De Mooij, M.; Hofstede, G. 2010. The Hofstede model applications to global branding and advertising strategy and research, International Journal of Advertising 29(1): 85-110.

http://dx.doi.org/10.2501/S026504870920104X

De Mooij, M.; Hofstede, G. 2002. Convergence and divergence in consumer behavior: implications for international retailing, Journal of Retailing 78: 61-69.

http://dx.doi.org/10.2501/S026504870920104X

DelVecchio, D. 2001. Consumer perceptions of private label quality: the role of product category characteristics and consumer use of heuristics, Journal of Retailing and Consumer Services 8(5): 239-249. http://dx.doi.org/10.1016/S0969-6989(00)00030-8

Dick, A.; Jain, A.; Richardson, P. 1996. How consumers evaluate store brands, Journal of Product and Brand Management 5(2): 19-28. http://dx.doi.org/10.1108/10610429610119405

Fernie, J.; Pierrel, R. A. 1996. Own branding in UK and French grocery markets, Journal of Product and Brand Management 5(3): 48-59. http://dx.doi.org/10.1108/10610429610126579

Gomez, M.; Fernandez, A. 2009. Consumer-level factors that influence store brand proneness: an empirical study with Spanish consumers, Journal of Euromarketing 18: 23-34.

http://dx.doi.org/10.1080/10496480902865207

Groznik, A.; Heese, H. S. 2010. Supply chain interactions due to store-brand introductions: the impact of retail competition, European Journal of Operational Research 203(3): 575-582.

http://dx.doi.org/10.1016/j.ejor.2009.08.014

Guerrero, L.; Colomer, Y.; Guardia, M. D.; Xicola, J.; Clotet, R. 2000. Consumer attitude towards store brands, Food Quality and Preference 11(5): 387-395.

http://dx.doi.org/10.1016/S0950-3293(00)00012-4

Halstead, D.; Ward, C. B. 1995. Assessing the vulnerability of private label brands, Journal of Product and Brand Management 4(3): 38-48. http://dx.doi.org/10.1108/10610429510097636

Hansen, K.; Singh, V. 2008. Are store brand buyers store loyal? An empirical investigation, Management Science 54(10): 1828-1834. http://dx.doi.org/10.1287/mnsc.1080.0861 
Hofstede, G. 2001. Cultured Consequences. 2nd edition. Thousand Oaks, CA: Sage.

Hofstede, G.; Hofstede, G. J. 2005. Cultures and Organizations, Software of the Mind. 2nd edition. New York, NY: McGraw-Hill.

Huang, Y.; Huddleston, P. 2009. Retailer premium own-brands: creating customer loyalty through own-brand products advantage, International Journal of Retail and Distribution Management 37(11): 975-992. http://dx.doi.org/10.1108/09590550910999389

Hyman, M. R.; Kopf, D. A.; Lee, D. 2010. Review of literature-future research suggestions: private label brands: benefits, success factors and future research, Journal of Brand Management 17(5): 368-389. http://dx.doi.org/10.1057/bm.2009.33

Jonas, A.; Roosen, J. 2005. Private labels for premium products-the example of organic food, International Journal of Retail and Distribution Management 33(8): 636-653.

http://dx.doi.org/10.1108/09590550510608412

Kara, A.; Rojas-Mendez, J.; Kucukemiroglu, O.; Harcar, T. 2009. Consumer preferences of store brands: role of prior experiences and value consciousness, Journal of Targeting, Measurement and Analysis for Marketing 17(2): 127-137. http://dx.doi.org/10.1057/jt.2009.6

Key Note. 2003. Supermarket Own Labels Market Assessment [online], [cited 23 March 2011]. Available from Internet: http://www.keynote.co.uk/market-intelligence/view/product/1267/supermarket-own-labels

Kilian, T.; Walsh, G.; Buxel, H. 2008. Measurement of attitude towards private labels: a replication and extension, European Retail Research 22: 69-85.

Kumar, N.; Steenkamp, J. B. E. M. 2006. Private Label Revolution. Boston: Harvard Business School Press.

Kumar, N.; Steenkamp, J. B. E. M. 2007. Private Label Strategy. Cambridge, MA: Harvard Business School Press.

Lymperopoulos, C.; Chaniotakis, I. E.; Rigopoulou, I. D. 2010. Acceptance of detergent-retail brands: the role of consumer confidence and trust, International Journal of Retail and Distribution Management 38(9): 719-736. http://dx.doi.org/10.1108/09590551011062457

Lyons, T. 2008. Tescos plot to counter Aldi effect, Supermarket giant plans new own-brand range to take on crunch-busting discount rivals [online], [cited 23 March 2011]. Available from Internet: http://business.timesonline.co.uk/tol/business/industry_sectors/consumer_goods/article4322497.ece

Malterud, K. 2001. Qualitative research: standards, challenges, and guidelines, Qualitative Research Series 358(9280): 483-488.

Mandhachitara, R.; Shannon, R. M.; Hadjicharalambous, C. 2007. Why private label grocery brands have not succeeded in Asia, Journal of Global Marketing 20(2/3): 71-87.

http://dx.doi.org/10.1300/J042v20n02_07

Martos-Partal, M.; Gonzalez-Benito, O. 2009. The effects of store brand loyalty on store loyalty: evidence from the Spanish market, The International Review of Retail, Distribution and Consumer Research 19(3): 273-288. http://dx.doi.org/10.1080/09593960903234200

McGoldrick, P. 2002 Retail Marketing. London: McGraw Hill.

Monroe, K. B.; Krishnan, R. 1985. The effect of price on subjective product evaluations, in Jacoby, J.; Olson, J. C. (Eds.). Perceived Quality: How Consumers View Stores and Merchandise. Lexington, MA: D.C. Heath and Company, 209-232.

Morris, D. 1979. The strategy of own brands, European Journal of Marketing 13(2): 59-78. http://dx.doi.org/10.1108/EUM0000000004930

Moss, G.; Vinten, G. 2001. Choices and preferences: testing the effect of nationality, Journal of Consumer Behavior 1(2): 198-208. http://dx.doi.org/10.1002/cb.65

Myers, J. G. 1967. Determinants of private brand attitude, Journal of Marketing Research 4: 73-81. http://dx.doi.org/10.2307/3150168 
Nandan, S.; Dickinson, R. 1994 Private brands: major brand perspective, Journal of Consumer Marketing 11(4): 18-28. http://dx.doi.org/10.1108/07363769410070863

Nishikawa, C.; Perrin, J. 2005. Private label grows global, Consumer Insights (winter): 27-31.

Qu, X. W. 1996. Chinese Lianmian Guan. Taipei: Guiguan, in Chinese.

Rao, A. R.; Monroe, K. B. 1989. The effect of price, brand name and store name on buyers perceptions of product quality: an integrative review, Journal of Marketing Research 26(August): 351-357. http://dx.doi.org/10.2307/3172907

Richardson, P. S. 1997. Are store brands perceived to be just another brand?, Journal of Product and Brand Management 6(6): 388-404. http://dx.doi.org/10.1108/10610429710190432

Richardson, P. S.; Jain, A. K.; Dick, A. 1996. Household store brand proneness: a framework, Journal of Retailing 72(2): 159-185. http://dx.doi.org/10.1016/S0022-4359(96)90012-3

Roth, M. S. 1995. The effects of culture and socioeconomics on the performance of global brand image strategies, Journal of Marketing Research 32: 163-175. http://dx.doi.org/10.2307/3152045

Samli, A. C. 1995. International Consumer Behavior: Its Impact on Marketing Strategy Development. Westport, CT: Quorum Books.

Schutte, H.; Ciarlante, D. 1998. Consumer Research in Asia. London: Macmillan.

Sinha, I.; Batra, R. 1999. The effect of consumer price consciousness on private label purchase, International Journal of Research in Marketing 16(3): 237-251.

http://dx.doi.org/10.1016/S0167-8116(99)00013-0

Steenkamp, J. B. E. M.; Dekimpe, M. G. 1997. The increasing power of store brands: building loyalty and market share, Long Range Planning 30(6): 917-930.

http://dx.doi.org/10.1016/S0024-6301(97)00077-0

Strauss, A.; Corbin, J. 1998. Basics of Qualitative Research. 2nd edition. Newbury Park, CA: Sage.

Suedo, K. 2004. Differences in the perception of face, in Jandt, F. E. (Ed.). Intercultural Communication. Thousand Oaks: Sage, 293-301.

Unsitalo, O. 2001. Consumer perceptions of grocery retail formats and brands, International Journal of Retail and Distribution Management 29(5): 214-225.

http://dx.doi.org/10.1108/09590550110390995

Veloutsou, C.; Gioulistanis, E.; Moutinho, L. 2004. Own labels choice criteria and perceived characteristics in Greece and Scotland: factors influencing the willingness to buy, Journal of Product and Brand Management 13(4): 228-241. http://dx.doi.org/10.1108/10610420410546943

Walsh, G.; Mitchell, V. W. 2010. Consumers intention to buy private label brands revisited, Journal of General Management 35(3): 3-24.

Zielke, S.; Dobbelstein, T. 2007. Customers willingness to purchase new store brands, Journal of Product and Brand Management 16(2): 112-121. http://dx.doi.org/10.1108/10610420710739982

Wei SONG received her PhD in Management from the University of Edinburgh, UK. She has had a solid international experience, including teaching at a range of universities and working at a major US corporation. She is a regular visiting professor at Chinese institutions while holding an Associate Professor post at Black Hills State University, U.S.A. Her research interests are in the areas of resource-based innovation in retail strategy, the U.K. own brand strategic model in emerging markets, Chinese consumer own label buying behavior and Chinese own brand strategy. She conducts research and publishes the papers regularly. In a consultation capacity, Dr Song serves as a senior consultant for both US and Chinese educational institutions. 